\title{
Rola kapitału społecznego w rozwoju obszarów wiejskich na przykładzie wsi Ruś
}

\section{The role of social capital in rural development as illustrated by the case of Ruś village}

\section{Marta GWIAŹDZIŃSKA-GORAJ ${ }^{1} \bullet$ Sebastian GORAJ ${ }^{1}$ Barbara SOBOLEWSKA-WĘGRZYN ${ }^{2}$}

\author{
${ }^{1}$ Uniwersytet Warmińsko-Mazurski w Olsztynie \\ Katedra Planowania i Inżynierii Przestrzennej \\ ul. Prawocheńskiego 15, 10-724 Olsztyn \\ marta.gwiazdzinska-goraj@uwm.edu.pl•sebastian.goraj@uwm.edu.pl
}

bswegrzyn@gmail.com

\begin{abstract}
Zarys treści: W rozwoju lokalnym coraz większą rolę przypisuje się czynnikom endogenicznym, wśród których ważnym zasobem jest kapitał społeczny. Kapitał społeczny najogólniej definiowany jest jako specyficzny rodzaj więzi łączących określone społeczności, istotnych w kreowaniu rozwoju lokalnego. Uaktywnienie kapitału społecznego następuje często w sytuacji zagrożenia interesu lokalnej wspólnoty. Rodzą się wówczas relacje, które mogą zaowocować współdziałaniami w nowych okolicznościach. W niniejszym opracowaniu zaprezentowano mobilizowanie kapitału społecznego podolsztyńskiej wsi Ruś na różnych płaszczyznach aktywności. Społeczność Rusi stanowi przede wszystkim młoda ludność napływowa charakteryzująca się wysokimi na ogół kwalifikacjami zawodowymi. Początkowo nie było formalnego lidera mobilizującego lokalną społeczność, wszelka aktywność miała często wymiar spontaniczny. Z czasem rolę liderów przejęli sołtys wsi Ruś, przy wsparciu rady sołeckiej, a także prezes i członkowie zarządu Stowarzyszenia Miłośników Rusi nad Łyną. Wysoka świadomość takich wartości, jak czyste, niezmienione środowisko przyrodnicze, ciągłość kulturowa miejsca zamieszkania czy więzi lokalne, wyzwalają działania, które kreują przestrzeń przyjazną mieszkańcom, a równocześnie otwartą na przybyszów.
\end{abstract}

Słowa kluczowe: kapitał społeczny, Ruś, obszary wiejskie.

\section{Wprowadzenie}

Rozwój lokalny według definicji J. Paryska (1997, s. 46) to kompleksowe kształtowanie możliwie najlepszych warunków życia w lokalnym środowisku, względnie doskonalenie organizacji, struktury i funkcjonowania lokalnego, terytorialnego systemu społecznego, głównie poprzez wykorzystanie lokalnych zasobów rozwoju. Specyfika rozwoju lokalnego, w odróżnieniu od rozwoju społeczno-gospodarczego w ogólnym znaczeniu, polega na tym, że jest on w dużej mierze pochodną endogenicznych czynników rozwoju (lokal- 
nych potrzeb, zasobów, specyfiki miejscowej ludności, lokalnych organizacji podmiotów gospodarczych). W Polsce rozwój lokalny i gospodarka lokalna zyskały podmiotowość z początkiem lat 90. ubiegłego wieku, w warunkach decentralizacji gospodarki w początkowym etapie transformacji ustrojowej. Wzrost roli samorządów, które przejęły większość funkcji związanych z miejscowym zarządzaniem, stworzył możliwość pełniejszego wykorzystania lokalnego potencjału.

Rozwój lokalny uzależniony jest od kilku grup czynników, wśród których należałoby wymienić: potrzeby (egzystencjalne, rezydencjalne, kulturalne, społeczne), zasoby (środowiska przyrodniczego, pracy, kapitału, kulturowe, zagospodarowanie infrastrukturalne, potencjał gospodarczy, potencjał intelektualny, instytucje lokalne), powiązania z otoczeniem zewnętrznym (usytuowanie w stosunku do centrów gospodarczych, dostępność komunikacyjna, udział w rynku zewnętrznym). Wyżej wymienione czynniki mogą być dwojako klasyfikowane: jako tzw. czynniki twarde, które mają byt rzeczywisty, są możliwe do sprecyzowania i zmierzenia, oraz tzw. czynniki miękkie, nie poddające się bezpośrednio kwantyfikacji (Brdulak 2011). O ile czynniki twarde mają ograniczone możliwości wzrostu, o tyle miękkie nie podlegają takim ograniczeniom. Nie istnieją w praktyce bariery dla aspiracji mieszkańców, kreatywności i innowacyjności kapitału ludzkiego, zaangażowania społeczności lokalnej w działalność publiczną, czyli twórczego identyfikowania się z miejscem zamieszkania. Wśród czynników miękkich istotną rolę odgrywa obecność lidera, jego wizja i odpowiedni poziom optymizmu, którym jest w stanie zarazić lokalną społeczność (Będzik 2010). Głównym celem pracy jest ukazanie okoliczności i przejawów uaktywnienia się kapitału społecznego we wsi Ruś w rozumieniu umiejętności współpracy międzyludzkiej w obrębie grup i organizacji w celu realizacji wspólnych potrzeb i interesów (Przybysz i Sauś 2004). Kapitał społeczny uzewnętrznił się w tym przypadku w postaci wzmożonej aktywności mieszkańców na rzecz kreowania przestrzeni przyjaznej do zamieszkania przy uwzględnieniu istniejących wysokich walorów przyrodniczych i kulturowych. Głównym źródłem informacji były bezpośrednie kontakty z miejscową społecznością. Obejmują one rozmowy przeprowadzone z mieszkańcami wsi, uczestnictwo w różnych formach aktywności społecznej mieszkańców wsi Ruś i bieżące monitorowanie przemian zachodzących w efekcie tej aktywności. Dodatkowym źródłem informacji był portal społecznościowy mieszkańców wsi.

\section{Charakterystyka obszaru badawczego - wsi warmińskiej Ruś}

Ruś jest wsią położoną w gminie Stawiguda, w strefie oddziaływania Miejskiego Obszaru Funkcjonalnego Olsztyna, usytuowaną w odległości $7 \mathrm{~km}$ na południe od miasta. Akt lokacyjny Rusi datowany jest na rok 1374, kiedy to kapituła warmińska osadziła na jej terenie pięciu pruskich bartników i nadała im po trzy włóki ziemi (Barczewski 1917). Według A. Triller (1974, za: Chłosta 2004) nazwa Ruś pochodzi z niemieckiego Raussen (więcierz) i jest związana z faktem, iż okoliczni mieszkańcy trudnili się głównie połowem ryb w rzece Łynie i pobliskich jeziorach. Według M. Hoffmana (2004) Ruś, położona na stromych stokach krawędzi doliny górnej Łyny, jest jedną z najpiękniejszych wsi warmińskich. Ze względu na zróżnicowaną rzeźbę terenu, przypominającą miejscowości podgórskie, w literaturze można spotkać się z określeniem Rusi i jej okolic jako Szwajcarii Warmińskiej. Wysokie walory przyrodnicze zadecydowały o tym, że wieś i okolice włączone zo- 
stały w ekologiczny system obszarów chronionych, który tworzą Obszar Chronionego Krajobrazu Doliny Pasłęki, Obszar Chronionego Krajobrazu Doliny Środkowej Łyny oraz kompleksy lasów o charakterze puszczańskim - Obszar Chronionego Krajobrazu Puszczy Napiwodzko-Ramuckiej. W miejscowości znajdują się dwa pomniki przyrody, a w 1982 r., w celu zachowania ochrony zespołów leśnych i wodnych, a także zwierząt i ptactwa, na skraju wsi utworzono Rezerwat Przyrody „Las Warmiński” im. prof. Benona Polakowskiego (Szymkiewicz 2004).

O atrakcyjności Rusi, poza wysokimi walorami przyrodniczymi, decyduje również materialne dziedzictwo kulturowe. Zachowany stary układ ruralistyczny wraz z najbliższym otoczeniem współtworzy osobliwy klimat miejsca, za sprawą którego W. Ogrodziński (2004) nazwał Ruś perłą wsi warmińskich. Na szczególną uwagę w zabudowie Rusi zasługuje zabytkowy młyn zbożowy o konstrukcji drewnianej, w którym niestety parę lat temu uległ zniszczeniu dach. Do rejestru zabytków wpisana została również dwukondygnacyjna kapliczka przydrożna zbudowana z czerwonej cegły datowana na rok 1887. Kapliczka została poddana renowacji w ramach programu „Ratujmy Kapliczki Warmińskie”, a obecnie staraniem lokalnego stowarzyszenia we współpracy z Radą Sołecką Wsi Ruś oraz mieszkańców renowacji poddawana jest rzeźba Trójcy Świętej. Elementem dawnego układu ruralistycznego jest również stosunkowo dobrze zachowana karczma. Jest to budynek dwukondygnacyjny z czerwonej cegły, ze spadzistym dachem, z widocznym, niewyraźnym napisem nad wejściem „Gasthauss”. W przeszłości karczma pełniła ważną funkcję „swoistego domu kultury” dla mieszkańców Rusi, obecnie jest to budynek mieszkalny. Kolejnym ważnym obiektem w Rusi była szkoła, początkowo drewniana, a od 1867 r. murowana. O znaczeniu szkoły może świadczyć fakt, iż z końcem lat 20. XX w. była jedyną szkołą wiejską czteroklasową w powiecie olsztyńskim (Chłosta 2004). Ze względu na zły stan techniczny wielokrotnie przebudowywany budynek został rozebrany i zastąpiony w 1988 r. nowym obiektem. W zabudowie mieszkaniowej Rusi początkowo dominowały budynki drewniane. Z czasem były one zastępowane przez zabudowę murowaną z czerwonej cegły na podmurówce kamiennej, z dachami pokrytymi dachówką, o kącie nachylenia $40-45^{\circ}$. Do rejestru zabytków na terenie wsi zostało wpisanych pięć chałup pochodzących z początku XX w. Najwięcej zachowanych starych budynków charakterystycznych dla zabudowy warmińskiej zlokalizowanych jest w starszej części wsi, położonej na dolnym jej piętrze, w sąsiedztwie rzeki Łyny. Na wzniesieniu, na górnym piętrze, udział starej zabudowy jest niewielki - dominują tam budynki nowe.

W Studium uwarunkowań i kierunków zagospodarowania przestrzennego gminy Stawiguda z 2012 r. wieś Ruś, ze względu na jakość przestrzeni kulturowej oraz stopień jej przekształceń, została zaliczona do zespołów ruralistycznych o wysokich wartościach kulturowych z elementami deformacji nową zabudową. W przeszłości Ruś wyróżniała się na tle sąsiadujących wsi wielofunkcyjnością, co wynikało m.in. z jej położenia nad rzeką. Istniały tu młyny zbożowe, tartaki, olejarnie, wytwórnie żelaza i miedzi, a gospodarcze znaczenie wsi było większe niż obecnie. Poza rolnikami mieszkali tu bartnicy, rybacy i młynarze. Ruś uchodziła za istotny punkt na trasie spływu Łyną drewna do Olsztyna i innych miast usytuowanych wzdłuż Łyny, a nawet do Królewca (Chłosta 2004). Położenie wsi przy starym Trakcie Niborskim prowadzącym z Olsztyna do Nidzicy (a szerzej z Warszawy do Królewca) sprawiało, że nie oszczędzały jej wojny. Często zdarzały się też klęski żywiołowe czy epidemie. Jako wieś pogranicza Ruś w 1920 r. objęta była plebiscytem, w wyniku którego znalazła się w granicach Prus Wschodnich. Okres międzywojenny to czas dyna- 
micznego rozwoju - zakładano tu niemieckie towarzystwa i instytucje, powstała ochotnicza straż pożarna, filia urzędu leśnego. Po II wojnie światowej ok. 75\% mieszkańców wyjechało za granicę, a funkcje gospodarcze wsi ograniczone zostały do rolnictwa. W planie ogólnym z 1991 r. Ruś określono jako wieś rolniczą o zwartej zabudowie, z architekturą charakterystyczną dla regionu warmińskiego, a także wybitnymi walorami krajobrazowymi. Przez ostatnie lata wieś zmieniła swój charakter - rolnicza przestrzeń produkcyjna ustąpiła miejsca przestrzeni mieszkaniowo-wypoczynkowej (ryc. 1). Obecnie we wsi funkcjonuje jedno indywidualne gospodarstwo rolne oraz Gospodarstwo Rybackie Olsztyn II Sp. z o.o., w którym większościowy pakiet udziałów nabyła spółka Gospodarstwo Rybackie "GOSŁAWICE” z siedzibą w Koninie, która zajmuje się hodowlą jesiotra i produkcją kawioru.

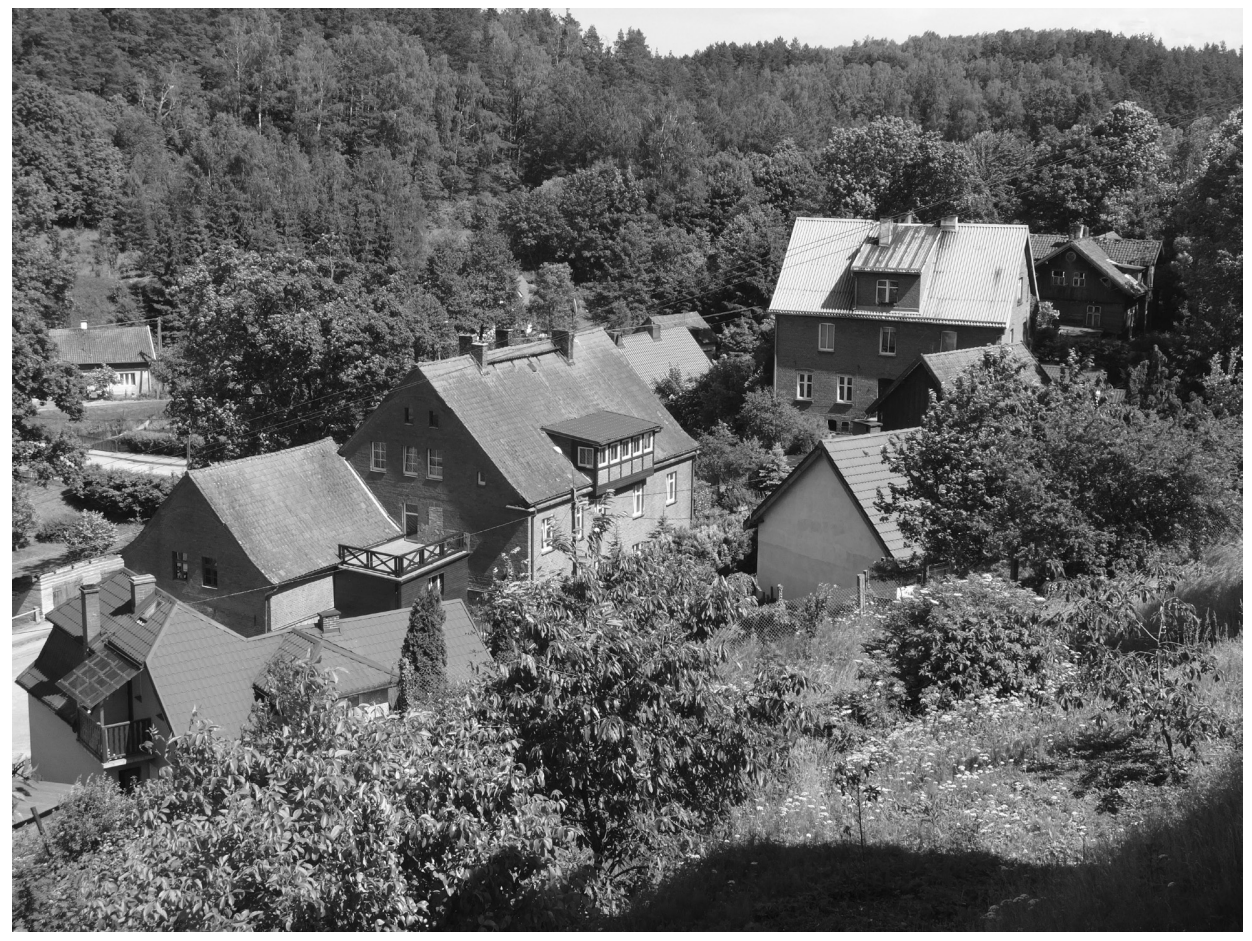

Fot. 1. Widok na zabudowę mieszkaniową w starej części wsi Ruś (fot. S. Goraj) Residential development in the old part of the village of Ruś (photo by S. Goraj)

Intensywny rozwój zabudowy mieszkaniowej Olsztyna w kierunku południowym spowodował, że pobliska Ruś i jej okolice stały się atrakcyjnym miejscem wypoczynku dla mieszkańców nowych dzielnic na południu Olsztyna. W rozwój funkcji rekreacyjnej Rusi opartej na lokalnym potencjale mocno wpisuje się uruchomienie w 2007 r. wyciągu narciarskiego Kartasiówka. Składa się on z trzech wyciągów orczykowych oraz czterech tras zjazdowych, każda po około $280 \mathrm{~m}$. Na miejscu można skorzystać z wypożyczalni sprzętu narciarskiego, a także wykupić lekcje w szkółce narciarskiej. Funkcja wypoczynkowa wsi, adresowana przede wszystkim do mieszkańców Olsztyna, ma szanse być uzupełniona o funkcję turystyczną, przy założeniu rozwoju zaplecza gastronomicznego i bazy nocle- 
gowej. Dodatkowo sprzyja temu atrakcyjne położenie Rusi w sąsiedztwie Olsztyna. Wraz z napływem ludności, a tym samym wprowadzeniem nowej zabudowy umacnia się coraz bardziej funkcja mieszkaniowa wsi.

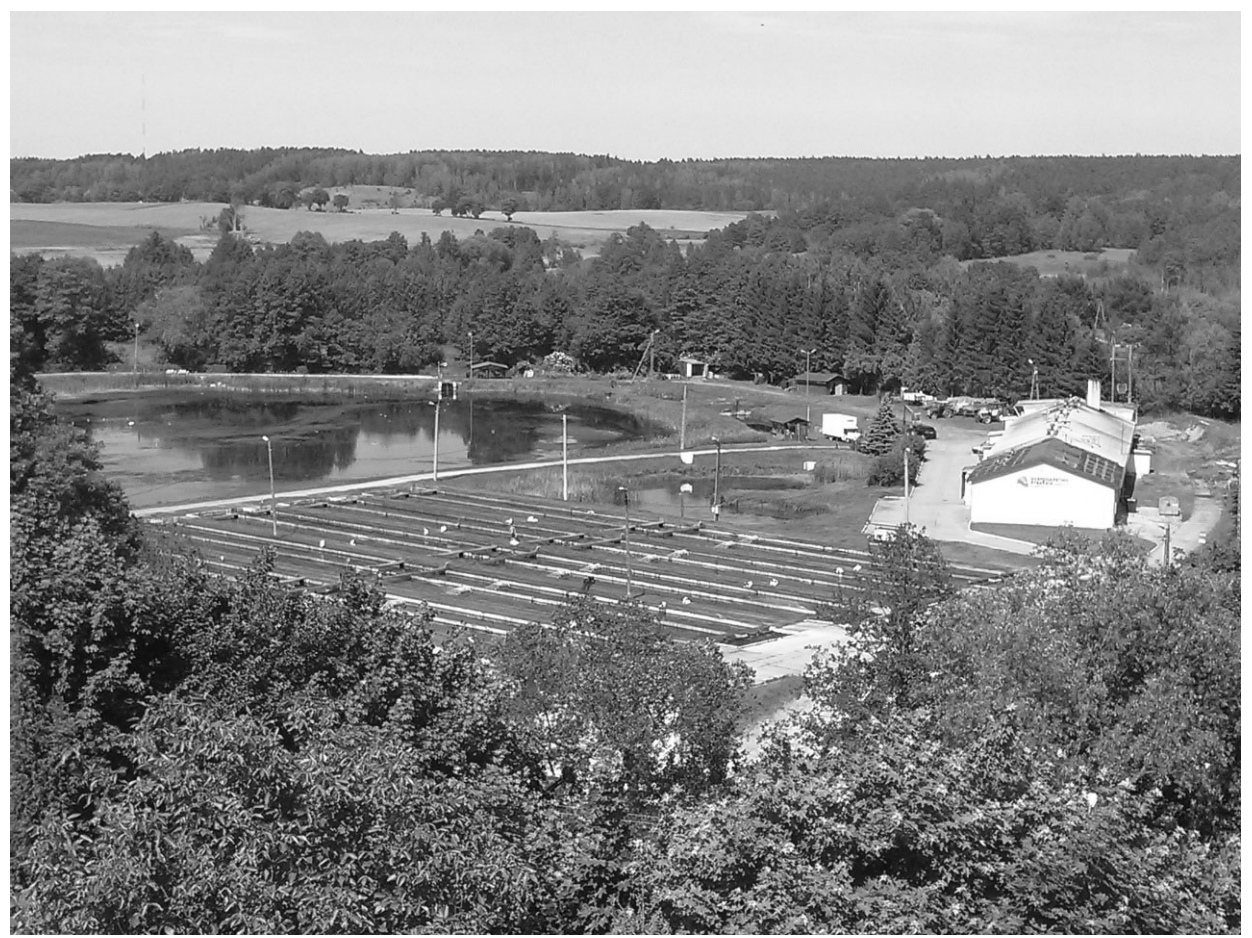

Fot. 2. Widok na gospodarstwo rybackie we wsi Ruś (fot. S. Goraj) Fishing farm in the village of Ruś (photo by S. Goraj)

Ruś ze względu na swoje walory przyrodniczo-kulturowe, a także stosunkowo niewielką odległość od Olsztyna jest atrakcyjnym miejscem do zamieszkania. Jednocześnie jej atrakcyjność wynika z niższej ceny ziemi i nieruchomości niż w Olsztynie. Według K. Kajdanek (2011) w świadomości mieszkańców miast silnie utrzymuje się obraz wsi jako miejsca dostarczającego ukojenia od miejskiego gwaru, zgiełku i hałasu. Zamieszkiwanie poza miastem jest zatem postrzegane nie tylko jako zdrowsze, tańsze, ale jest także realizacją długo odkładanego marzenia o posiadaniu nieruchomości na własność (Kajdanek 2011, s. 39).

Tabela 1. Liczba ludności wsi Ruś

\begin{tabular}{|l|c|c|c|c|c|c|c|}
\hline Rok & 2010 & 2011 & 2012 & 2013 & 2014 & 2015 & 2016 \\
\hline Liczba ludności & 423 & 440 & 456 & 449 & 456 & 459 & 458 \\
\hline
\end{tabular}

Źródło: www.stawiguda.pl/dane-statystyczne

W przypadku Rusi, podobnie, jak wynika z badań K. Kajdanek prowadzonych w strefie podmiejskiej Wrocławia, nowych mieszkańców strefy podmiejskiej cechuje ukształtowany miejski styl życia, określone przyzwyczajenia i oczekiwania wobec nowego miejsca 
zamieszkania. Z jednej strony wciąż związani są oni z miastem centralnym swoją osobistą historią i zależnościami funkcjonalnymi (pracą, edukacją dzieci), z drugiej strony chcą się od niego uwolnić i uciekają na wieś (Kajdanek 2011 s. 64).

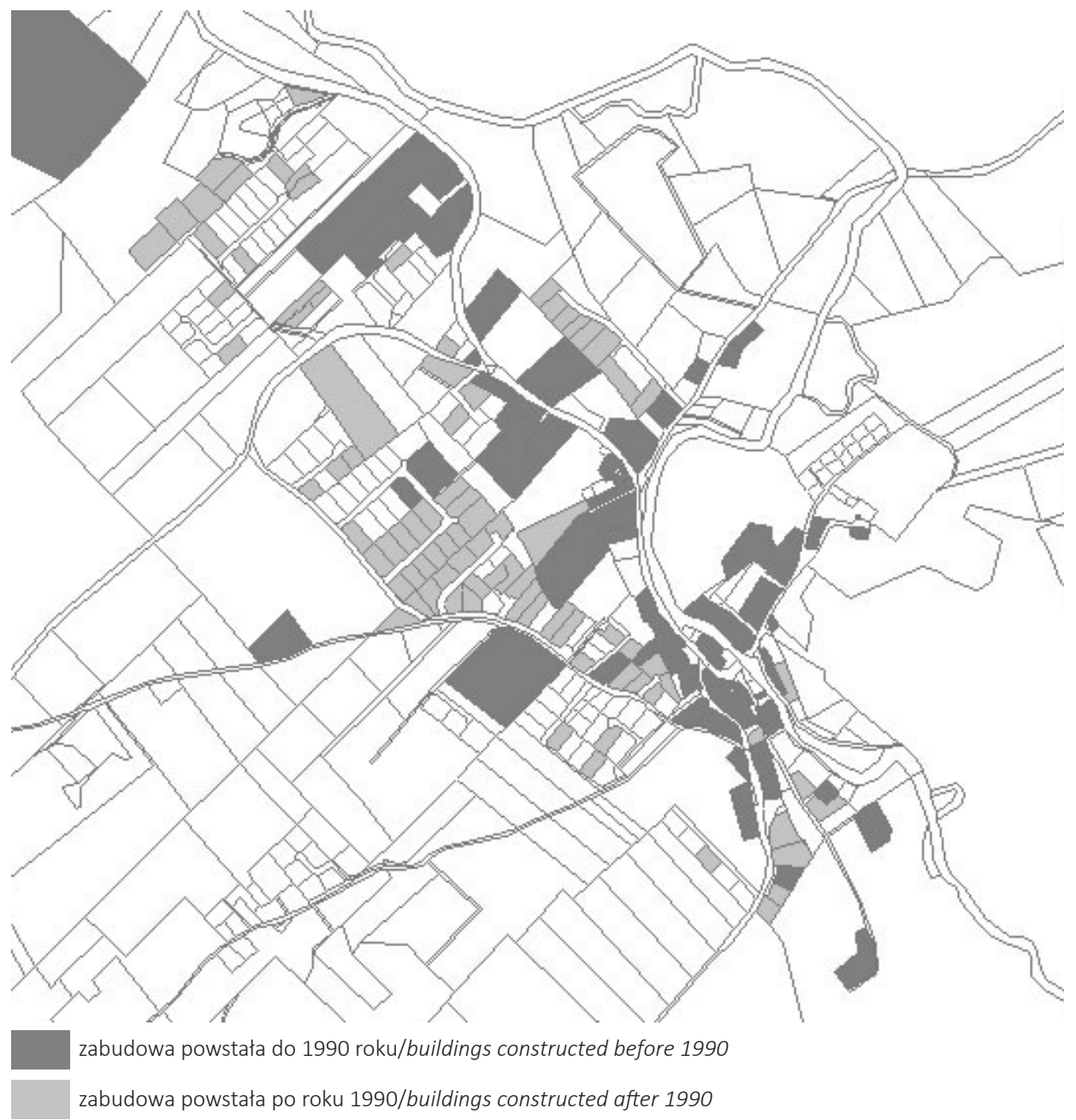

Ryc. 1. Zabudowa we wsi Ruś

Źródło: opracowanie własne, podkład mapowy Starostwo Powiatowe w Olsztynie/geoportal 2.

Buildings in the village of Ruś

Source: own study, background map of the District Office in Olsztyn / geoportal 2. 


\section{Kapitał społeczny w wymiarze społecznej aktywności mieszkańców Rusi}

Termin kapitał społeczny pojawiał się w opracowaniach, głównie socjologów, już w drugiej dekadzie XX W., jednak pierwsze teoretyczne koncepcje odnoszące się do kapitału społecznego sformułowane zostały dopiero w latach 80. ubiegłego wieku. W badaniach nad kapitałem społecznym zarysowały się dwa podejścia - strukturalne i normatywne - w różny sposób określające jego kluczowe elementy. Podejście strukturalne reprezentował francuski socjolog Pierre Bourdieu (1986). Zakładał on, że kapitał społeczny zawarty jest w strukturze relacji wewnątrz i zewnątrzgrupowych i jest zbiorem aktualnych i potencjalnych zasobów połączonych w sieć stosunków społecznych (Frykowski i Starosta 2008). Czołowi twórcy koncepcji normatywnych - Robert Putnam (1995) i Francis Fukuyama (1997) - odwoływali się do uwarunkowanych kulturowo tradycji obywatelstwa. Według koncepcji normatywnych pojęcie kapitału społecznego odnosi się do czynników społecznej organizacji, takich jak zaufanie, normy i sieci, które mogą poprawić efektywność społeczeństwa poprzez podejmowanie skoordynowanych działań (Sztompka 2007, s. 244). Oba podejścia - strukturalne i normatywne - stały się podstawą do formułowania syntetycznych definicji kapitału społecznego nawiązujących do założeń obu koncepcji. James Coleman (1994, za: Frykowski 2008, s. 34) dostrzega istotę kapitału społecznego w strukturze relacji wewnątrz i zewnątrzgrupowych bazujących na „zaufaniu, informacji, normach i efektywnych sankcjach, relacjach władzy i autorytetu i stopniu zobowiązań w ramach grupy". W większości koncepcji wyraźnie zaznaczają się trzy komponenty: sieć komunikacji i uczestnictwa, zaufanie i podzielane wartości i normy. Na przełomie stuleci problematyka kapitału społecznego znajdowała odbicie zarówno w pracach teoretycznych, jak i w badaniach empirycznych prowadzonych przez socjologów, politologów czy ekonomistów, co wynika z wieloaspektowości zagadnienia. Na gruncie polskiej literatury problematyką kapitału społecznego zajmowali się $m$ in.: J. Przybysz i J. Sauś (2004), T. Zarycki (2004, 2008), P. Sztompka (2007, 2016), J. Bartkowski (2007) i J. Działek (2011). Większość prac z tego zakresu ma charakter empiryczny, przy czym na uwagę zasługuje duże zaangażowanie geografów (Rosner i Stanny 2007; Janc 2009; Heffner 2010, Kacprzak 2010; Miszczuk 2010, Kamińska 2011), którzy skupiają się przede wszystkim na przestrzennym zróżnicowaniu kapitału społecznego w oparciu o wybrane mierniki (Bednarek-Szczepańska 2013). Najczęściej stosowaną miarą społecznego zaangażowania jest udział w działalności stowarzyszeniowej wyrażany poprzez liczbę organizacji pozarządowych. Takie podejście badawcze wynika z powszechnej dostępności informacji na ten temat, aczkolwiek jak pisze J. Działek (2011), wykorzystanie jednego wskaźnika prowadzi do zubożenia rzeczywistości i pominięcia wielu istotnych interakcji społecznych. W analizach empirycznych stosowane są często kombinacje różnych miar, np.: frekwencja wyborcza, członkostwo w klubach i zespołach, czytelnictwo prasy lokalnej, wykształcenie radnych (Bednarek-Szczepańska 2013). Zakładając, że kapitał społeczny stanowi pewien potencjalny zasób połączonych w sieć stosunków społecznych, może się on uaktywniać w określonych okolicznościach poprzez mobilizację sieci osobistych powiązań. Dokonanie pomiaru kapitału społecznego w skali lokalnej jest tym samym bardzo trudne. W tej sytuacji w badaniu społeczności lokalnych przydatne okazuje się podejście monograficzne. Takie stanowisko reprezentuje m.in. M. Bednarek-Szczepańska (2013), zwracając uwagę, że zbyt mało jest jeszcze opracowań o charakterze jakościowym, dotyczących konkretnych społeczności wiejskich, które uka- 
zywałyby okoliczności budowania kapitału społecznego i wykorzystania jego zasobów w różnych aspektach rozwoju lokalnego. Niniejsze opracowanie wychodzi naprzeciw tym oczekiwaniom. Przedstawia okoliczności, w jakich dochodzi do uaktywnienia kapitału społecznego i ewolucję celów realizowanych z wykorzystaniem zaistniałych więzi społecznych. W przypadku wsi Ruś ukształtowała się grupa inicjatywna mieszkańców, która zmobilizowała miejscową ludność do wspólnego działania. Uaktywnienie lokalnych zasobów kapitału społecznego nastąpiło w okolicznościach opisywanych często w literaturze jako bezpośrednie zagrożenie interesu lokalnej wspólnoty lub potrzeba załatwienia konkretnej sprawy (Dmochowska-Dudek 2011). W tym przypadku punktem wyjścia była ochrona nienaruszalności stanu środowiska przyrodniczego, jego wyjątkowych walorów stanowiących o jakości życia mieszkańców wsi Ruś. Uaktywnienie miejscowej społeczności nastąpiło przede wszystkim w związku z planem uruchomienia w sąsiedztwie wsi kopalni kruszywa. Podejmowane działania mające na celu zachowanie istniejących walorów przyrodniczych przyczyniły się do tworzenia więzi społecznej pomiędzy mieszkańcami. Początkowo nie było formalnego lidera mobilizującego lokalną społeczność do działania, a wszelka aktywność miała często wymiar spontaniczny. Z czasem powstała potrzeba wykreowania lokalnego przywódcy, który byłby osobą zaufaną. Zaufanie bowiem to szczególny ludzki pomost do niepewnego przyszłego świata, w którym centralną rolę odgrywają inni ludzie. Ufać, to znaczy wierzyć, iż rezultaty czyichś zamierzonych działań będą właściwe z naszego punktu widzenia (Sztompka 2007). W przypadku kapitału społecznego Rusi mamy do czynienia z zaufaniem definiowanym przez N. Luhmanna (1979) jako zaufanie, które jest okazywane z góry, w tym przypadku liderom, jako zaliczka na poczet powodzenia, w tym przypadku działań mających na celu kreowanie przestrzeni przyjaznej mieszkańcom, przy uwzględnieniu istniejących wysokich walorów przyrodniczych i kulturowych. W pierwszym etapie rolę lidera objął sołtys wsi Ruś przy wsparciu rady sołeckiej. Z czasem, ze względu na potrzebę sformalizowania podejmowanych działań społeczności, powołano w 2011 r. Stowarzyszenie Miłośników Rusi nad Łyną, w którym ciężar lidera przejął prezes i członkowie zarządu. Powstanie stowarzyszenia, uczestnictwo w zebraniach, a także zaangażowanie w działania na rzecz społeczności Rusi to istotne składowe kapitału społecznego wsi. R. Putnam (2000) na podstawie prowadzonych badań stworzył złożony indeks kapitału społecznego, który obejmuje takie elementy, jak przynależność do dobrowolnych stowarzyszeń i uczęszczanie na ich zebrania, uczestnictwo w spotkaniach publicznych, wiecach itp., podejmowanie dobrowolnych działań na rzecz wspólnoty, organizowanie przyjęć dla znajomych i uczęszczanie na takie przyjęcia, udział w wyborach i wreszcie - uogólnione zaufanie (Sztompka 2007).

Inicjowane przez liderów uaktywnianie kapitału społecznego w Rusi uwidacznia się w trzech płaszczyznach:

- działaniach zmierzających do zachowania ciągłości historycznej zamieszkałego obszaru, nawiązujących do dziedzictwa kulturowego,

- działaniach na rzecz stanu środowiska przyrodniczego i realizacji przedsięwzięć zmierzających do poprawy jakości zamieszkiwanej przestrzeni,

- działaniach na rzecz aktywności, współpracy, integracji społecznej i międzypokoleniowej.

Kreatorami przedsięwzięć zmierzających do popularyzacji wiedzy o historii regionu są prezes i członkowie Stowarzyszenia Miłośników Rusi nad Łyną. Pierwszą spektakularną inicjatywą tej grupy było postawienie w 2010 r. tablicy upamiętniającej trakt Gościniec 
Niborski, który był fragmentem dawnej drogi z Warszawy przez Nidzicę do Olsztyna i dalej do Królewca. Gościńcem tym podróżował między innymi Mikołaj Kopernik, a także korzystali z niego mieszkańcy dóbr ziemskich kapituły warmińskiej. Z okazji odsłonięcia tablicy odbył się happening z udziałem mieszkańców i aktora w roli Mikołaja Kopernika. Równocześnie zostały zebrane i opracowane materiały do wydania książki poświęconej traktowi, zatytułowanej Gościniec Niborski. Został również złożony wniosek o wpisanie tego historycznego fragmentu drogi do rejestru zabytków. Inspiracją do zorganizowania w 2011 r. pierwszego Dwuboju Flisackiego z Rusi do Olsztyna było także wydarzenie z przeszłości. Inicjatywa ta nawiązuje do tradycji spławiania drewna przez flisaków tratwami do Olsztyna, przy czym powrót do domu odbywał się rowerami, co można uznać za swoisty rodzaj „dwuboju”. Kolejne działanie podjęte przez członków Stowarzyszenia Miłośników Rusi nad Łyną skupiło się na zbieraniu materiałów dotyczących związku węgierskiego rodu Kalnassy z ziemią Warmii, czego efektem było współfinansowanie kopii pamiątkowej tablicy oraz wydanie Pieśni polskich i węgierskich Ferdynanda Gregoroviusa rodem z mazurskiej Nidzicy, pisanych ku czci Polaków i Węgrów walczących o niepodległość swych ojczyzn. W 2015 r. natomiast członkowie Stowarzyszenia zebrali część kwoty potrzebnej na renowację rzeźby Trójcy Świętej Kapliczki w Rusi; pozostała kwota została pozyskana z funduszu sołeckiego.

Liderem działań z zakresu realizacji przedsięwzięć zmierzających do poprawy jakości zamieszkiwanej przestrzeni jest przede wszystkim sołtys wsi wraz z radą sołecką. Działania te są finansowane z budżetu gminy Stawiguda lub z pozyskanych przez nią środków zewnętrznych. Ostatnio zrealizowane projekty to:

- remont i naprawa skarp przy drogach,

- utwardzenie drogi w górnej części wsi Ruś oraz montaż progów zwalniających,

- budowa przystani dla kajaków,

- modernizacja stacji uzdatniania wody (mająca wyrównać ciśnienie wody w sieci),

- remont kapitalny drogi zwanej zwyczajowo przez mieszkańców „Na Łąki”,

- budowa placu zabaw dla dzieci przy szkole podstawowej (projekt gminy Stawiguda realizowany na terenie kilku sołectw),

- budowa sieci kanalizacyjnej do Muchorowa,

- budowa oświetlenia ulicznego górnej Rusi.

Wszelkie inicjatywy związane z zagospodarowaniem przestrzeni podejmowane są przy pełnym wsparciu mieszkańców, czynnie włączających się w różnego rodzaju działania. Kapitał społeczny uzewnętrznił się najwyraźniej w zaangażowaniu mieszkańców przy zakładaniu parku. W 2015 r. mieszkańcy dwukrotnie „skrzyknęli się”, aby wspólnie uczestniczyć w pracach przygotowujących teren pod park. Dzięki zaangażowaniu niemal całej społeczności, również najmłodszej, pomiędzy szkołą a świetlicą wiejską powstał pięknie zaaranżowany park z siłownią zewnętrzną, który stał się miejscem wypoczynku i rekreacji mieszkańców Rusi i okolic.

Działania na rzecz aktywności, współpracy, integracji społecznej i międzypokoleniowej odbywają się z inicjatywy różnych grup mieszkańców i są realizowane głównie w świetlicy wiejskiej. Jest to miejsce spotkań całej społeczności - od najmłodszych do najstarszych. Dla dzieci i młodzieży odbywają się organizowane przez Gminny Ośrodek Kultury różnego rodzaju zajęcia: plastyczne, teatralne, projekcje bajek, zarówno w ciągu roku szkolnego, jak i w czasie ferii zimowych i wakacji letnich. Dorośli mogą uczestniczyć w kursach decoupage, aerobiku, zajęciach komputerowych i innych, zgodnie z oczekiwaniami miejscowej 
społeczności. Każde święto jest tu w szczególny sposób celebrowane. Co roku organizowane są wspólne Mikołajki, Wigilia, jest obchodzony Dzień Dziecka, Dzień Kobiet, Dzień Sołtysa, Dzień Flagi. Mieszkańcy Rusi chętnie uczestniczą w Wielkiej Orkiestrze Świątecznej Pomocy. We wsi działa także Koło Gospodyń Wiejskich „Baby Ruśkie”, które prężnie się rozwija, zrzeszając coraz liczniejsze grono pań w różnym wieku, chętnych do podejmowania wspólnej aktywności.

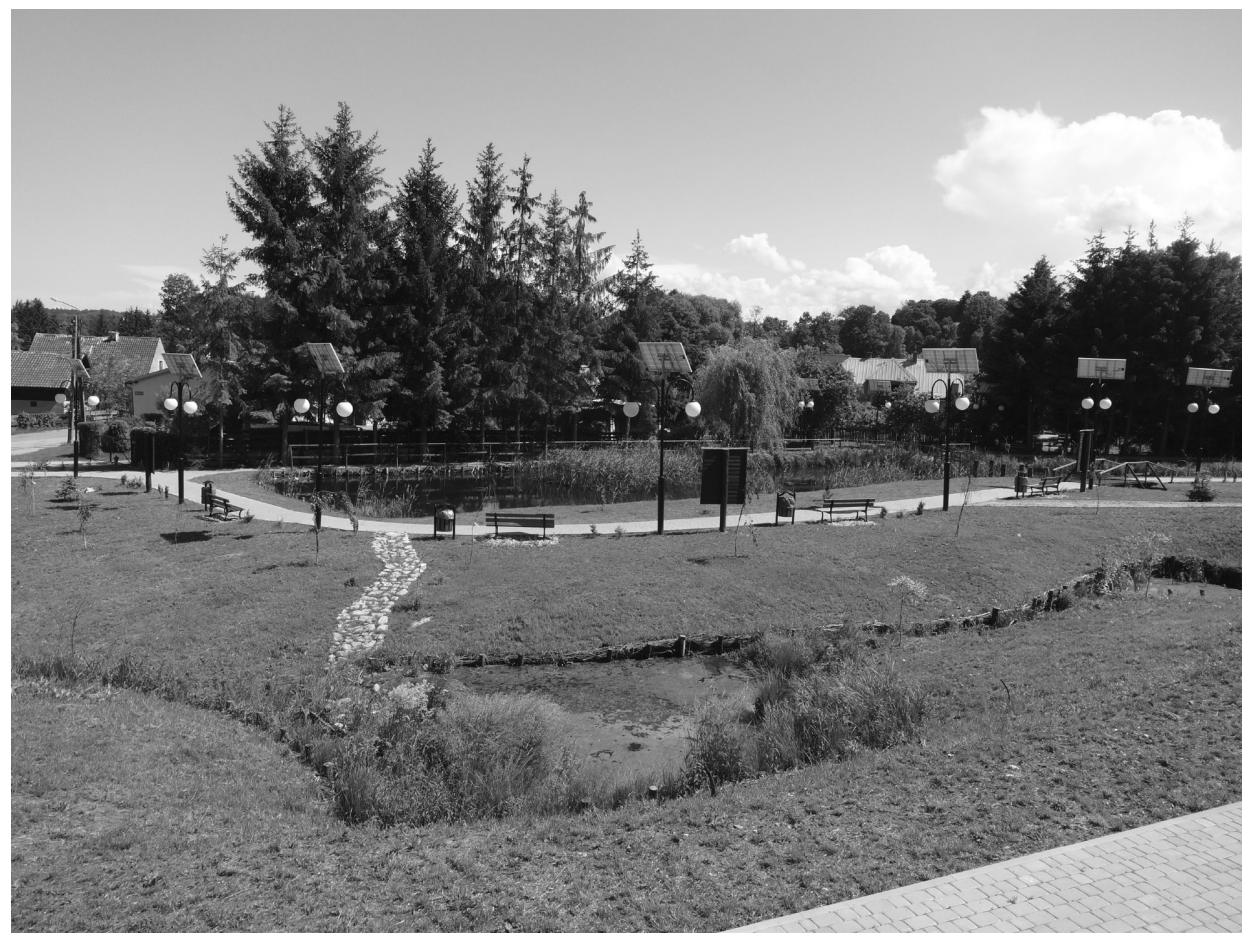

Fot. 3. Widok na park we wsi Ruś (fot. S. Goraj)

View of the park in the Ruś village (photo by S. Goraj)

Ważną rolę w integracji i przekazywaniu informacji ma strona internetowa utworzona przez sołtysa wsi „Ruś nad Łyną”, która pełni rolę wirtualnej tablicy ogłoszeń bardzo pomocnej przy realizacji różnorodnych działań.

\section{Podsumowanie}

Kapitał społeczny wsi Ruś został uaktywniony przede wszystkim w związku z planem uruchomienia w jej sąsiedztwie kopalni kruszywa. Podejmowane działania mające na celu zachowanie istniejących walorów przyrodniczych przyczyniły się do tworzenia więzi społecznej pomiędzy mieszkańcami. Początkowo rolę lidera objął sołtys wsi, przy wsparciu rady sołeckiej, a z czasem ze względu na potrzebę sformalizowania podejmowanych działań społeczności powołano stowarzyszenie. Powstanie stowarzyszenia, uczestnictwo w zebraniach, a także zaangażowanie w działania na rzecz społeczności Rusi to istotne 
składowe kształtującego się kapitału społecznego wsi. Nowi mieszkańcy Rusi, którzy wybrali to miejsce do zamieszkania to przede wszystkim osoby, które dokonały świadomego wyboru „swojego miejsca na ziemi”, stąd silna identyfikacja z zamieszkiwaną przestrzenią i potrzeba „zakorzenienia”. Wysoka świadomość takich wartości, jak czyste, niezmienione środowisko przyrodnicze, ciągłość kulturowa miejsca zamieszkania czy więzi lokalne, wyzwoliły działania, dzięki którym kreują przestrzeń przyjazną mieszkańcom, a równocześnie otwartą na przybyszów.

\section{Literatura}

Barczewski W., 1917, Geografia Polskiej Warmii, Odbitka z Gazety Olsztyńskiej, Olsztyn.

Bartkowski J., 2007, Kapitał społeczny i jego oddziaływanie na rozwój w ujęciu socjologicznym, [w:] M. Herbst (red.), Kapitał ludzki i kapitał społeczny a rozwój regionalny, Wydawnictwo Naukowe Scholar, Warszawa.

Bednarek-Szczepańska M., 2013, Wiejski kapitał społeczny we współczesnej Polsce. Przeglad badań i uwagi metodyczne, Acta Universitatis Lodziensis Folia Geografica Socio-Oeconomica, 13, Wydawnictwo Uniwersytetu Łódzkiego, Łódz, s. 19-40.

Bednarek-Szczepańska M., 2014, Znaczenie syndromu NIMBY dla gospodarki przestrzennej. Przykłady konfliktów lokalizacyjnych na obszarach wiejskich w Polsce, [w:] S. Ciok, K. Janc (red.), Współczesne wyzwania polityki regionalnej i gospodarki przestrzennej, Rozprawy Naukowe Instytutu Geografii i Rozwoju Regionalnego Uniwersytetu Wrocławskiego, 33/2, t. 2, Wydawnictwo Uniwersytetu Wrocławskiego, Wrocław, s. 149-160.

Będzik B., 2010, Deficyt kapitału społecznego zwiastunem nadchodzq̨cych kłopotów, Acta Scientarium Polonorum Oeconomia, 9 (1), Wydawnictwo Uniwersytetu Warmińsko-Mazurskiego, s. $15-22$.

Bourdieu P., 1986, The Forms of Capital [w:] J.G. Richardson (red.), Handbook of Theory and Research for the Sociology of Education, Macmillan, New York, s. 241-258.

Brdulak J., 2011, Cechy rozwoju lokalnego, Praktyczna Teoria.pl - serwis internetowy Kolegium Nauk o Przedsiębiorstwie SGH; http://www.praktycznateoria.pl/cechy-rozwoju-lokalnego/

Coleman J.S., 1994, Foundation of Social Theory, Harvard University Press, Cambridge, MA.

Chłosta J., 2004, Z przeszłości podolsztyńskiej Rusi, [w:] Ruś nad Łynq, Agencja WIT Witold Mierzejewski, Olsztyn, s. 33-58.

Dmochowska-Dudek K., 2011, Obiekty nimby jako przykład konfliktowych inwestycji na terenach mieszkaniowych - teoretyczny zarys problemu, [w:] J. Dzieciuchowicz (red.), Współczesne przemiany środowiska mieszkaniowego - wybrane problemy, Space - society - economy, 10, Łódź, s. 29-56.

Działek J., 2011, Kapitał społeczny - ujęcie teoretyczne i praktyka badawcza, Studia Regionalne i Lokalne, 3 (45), Wydawnictwo Centrum Europejskich Studiów Regionalnych i Lokalnych UW i Wydawnictwo Naukowe SCHOLAR, s. 100-118.

Facebook - strona Rusi nad Łyną

Frykowski M., Starosta P., 2008, Kapitał społeczny i jego użytkownicy, Przegląd Socjologiczny, LVII/1, Łódzkie Towarzystwo Naukowe (ebook), s. 31-62.

Fukuyama F., 1997, Zaufanie: kapitał społeczny a droga do odbrobytu, PWN, Warszawa-Wrocław.

Heffner K., 2010, Rozwój obszarów wiejskich w województwie opolskim (znaczenie kapitału ludzkiego i społecznego), [w:] W. Kamińska, K. Heffner (red.), Kapitał ludzki i społeczny w procesie rozwoju obszarów wiejskich, Studia KPZK PAN, CXXVI, Warszawa. 
Hoffmann M.J., 2004, Najstarsze dzieje Rusi i okolic, [w:] Ruś nad Łynq, Agencja WIT Witold Mierzejewski, Olsztyn, s. 9-32.

Janc K., 2009, Zróżnicowanie przestrzenne kapitału ludzkiego i społecznego w Polsce, Instytut Geografii i Rozwoju Regionalnego Uniwersytetu Wrocławskiego, Wrocław.

Kacprzak E., 2010, Social Capital in the Process of Rural Development in the Wielkopolska Province, Roczniki Naukowe Stowarzyszenia Ekonomistów Rolnictwa i Agrobiznesu, 12, 6.

Kajdanek K., 2011, Pomiędzy miastem a wsiq: suburbanizacja na przykładzie osiedli podmiejskich Wrocławia, Zakład Wydawniczy „Nomos”, Kraków.

Kamińska W., 2011, Kapitał ludzki i społeczny na obszarach wiejskich w Polsce: przykład województwa świętokrzyskiego, Wydawnictwo Uniwersytetu Humanistyczno-Przyrodniczego, Kielce.

Luhmann N.,1979, Trust and Power, John Wiley, New York.

Miszczuk A., 2010, Kapitał ludzki i społeczny w procesie rozwoju obszarów wiejskich województwa lubelskiego, [w:] W. Kamińska, K. Heffner (red.), Kapitał ludzki i społeczny w procesie rozwoju obszarów wiejskich, Studia KPZK PAN, CXXVI, Warszawa.

Ogrodziński W., 2004, Olsztyn przed nami, [w:] Ruś nad Łynq, Wydawca Agencja WIT Witold Mierzejewski, Olsztyn, s. 91-102.

Parysek J.J., 1997, Podstawy gospodarki lokalnej, Wydawnictwo Naukowe im. Adama Mickiewicza w Poznaniu, Poznań.

Przybysz J., Sauś J., 2004, Kapitał społeczny. Szkice socjologiczno-ekonomiczne, Wydawnictwo Politechniki Poznańskiej, Poznań.

Putnam R., 1995, Demokracja w działaniu: tradycje obywatelskie we współczesnych Włoszech, Wydawnictwo Znak, Kraków.

Putnam R., 2000, Bowling Alone: Collapse and Revival of American Community, Simon and Schuster, New York.

Rosner A., Stanny M., 2007, Zróżnicowanie poziomu rozwoju obszarów wiejskich według komponentu społecznego, [w:] A. Rosner (red.), Zróżnicowanie poziomu rozwoju społeczno-gospodarczego obszarów wiejskich a zróżnicowanie dynamiki przemian, IRWiR PAN, Warszawa, s. 47-114.

Studium uwarunkowań i kierunków zagospodarowania przestrzennego gminy Stawiguda. Kierunki Zagospodarowania Przestrzennego, 2012, Stawiguda.

Sztaudynger J.J., 2005, Wzrost gospodarczy a kapitał społeczny, prywatyzacja i inflacja, Wydawnictwo Naukowe PWN, Warszawa.

Sztompka P., 2007, Zaufanie. Fundament społeczeństwa, Wydawnictwo Znak, Kraków.

Sztompka P., 2016, Kapitał społeczny. Teoria przestrzeni międzyludzkiej, Wydawnictwo Znak, Kraków.

Szymkiewicz M., 2004, Osobliwości świata zwierzq̨t okolic Rusi, [w:] Ruś nad Łynq, Agencja WIT Witold Mierzejewski, Olsztyn, s. 77-90.

www.stawiguda.pl/dane-statystyczne

Triller A., 1974, Geschichte der Pfarrei Grob Bertung Kr. Allenstein, Zeitschrift für die Geschichte und Altertumskunde Ermlands, 37, s. 9-55.

Zarycki T., 2008, Dwa wymiary kapitału społecznego w kontekście polskim, Pomorski Przegląd Gospodarczy, 2, 37, s. 49-52.

Zarycki T. 2004. Kapitał społeczny a trzy polskie drogi do nowoczesności, Kultura i społeczeństwo, 48 (2), s. 45-65. 


\section{Summary}

The social capital of the village of Ruś has been activated primarily in connection with the plan to launch a mining village in the vicinity of the village. Actions taken to preserve existing natural values contributed to creating a social bond between the inhabitants. Initially, the leadership of the village was taken over by the village headman of Ruś, with the support of the village council, and with time, due to the need to formalize the activities of the community, an association was established. The rise of the association, participation in the meetings and commitment to the Ruś community are important components of the emerging social capital of the countryside. New residents of Ruthenia, who have chosen this place as their home after 2000, are primarily those who have made an informed choice of "their place on earth", hence strong identification with the living space and the need to "root". High awareness of such values as the clean, unchanged natural environment, the cultural continuity of the place of residence or local ties have freed up activities that create a friendly space for the inhabitants while being open to newcomers. 
http://rcin.org.pl 